\title{
26 Building human capacity to transform agriculture in Southern Africa
}

\author{
Anusuya Rangarajan and Joyce Chitja
}

\section{Introduction}

Recent estimates indicate that $90 \%$ of the world's farms are family owned and operated, and 84\% of those families farm on less than 2 ha (Lowder et al., 2016). Small farms (less than $20 \mathrm{ha}$ ) supply diverse and nutritious products to local food systems while advancing household food security (Herrero et al., 2017). Among the Southern African Development Countries (SADC), smallholder farmers represent the majority of producers, farming an average of 1 to $5 \mathrm{ha}$. The government of South Africa recognizes small-scale agriculture as a potentially sustainable contributor to food security (Altman et al., 2009) and as a development strategy in the 2010 National Development Plan (Wiggins and Keats, 2013) because it increases household income and nutrition with minimal investment.

To continue to thrive these farmers constantly change their practices and leverage their limited assets and resources in creative ways. Developing this type of nonmaterial ability or agency refers to the ability of smallholders and their organizations to position themselves in a market, to make effective choices to advance their interests and to be able to act on those choices (Sonia, 2012). This type of creative adaptation is underpinned by social networks, education and training and personal motivation and planning and risk management. This type of agency is not static; in fact the dynamic nature of learning, sharing information, reflection, innovation and anticipation or forward planning more completely describes the adaptation process that is fundamental to building resilient farming systems (Tschakert and Dietrich, 2010). The key policy and practice question is how can research, extension and policy support the development of human adaptive capacity or agency of smallholder farmers and thereby support continuous transformation of agriculture?

Smallholder farmers in Southern Africa, and around the world, face several critical challenges to their long-term viability and sustainability. These challenges can be briefly summarized within production strategies, access to land and inputs, access to markets, relevant training, farmer organizational capacity and capability, appropriate technology and entrepreneurship and business development. 
Perhaps the most pressing production challenge being faced by smallholders is adaptation to climate change. Ecologically and economically resilient and relevant farming strategies are needed to overcome the drought, flood and temperature perturbations associated with climate change. Solutions need to be scale and resource relevant, quickly adaptable by women farmers and have some immediate measurable benefit to farm productivity to secure implementation long-term. Many technologies are available that meet these criteria- but outreach is limited by labour hours and strategies used by educators.

In South Africa and to an extent in Zimbabwe, there is another fundamental challenge particularly for black smallholder farmers- new farm startup. While repatriation is celebrated, the reality is that many returning to the land find they lack knowledge on starting and growing a farm business. Traditional knowledge has been lost given generations out of farming; new farming technologies are not readily accessible if one is unaware of the supportive networks for information flows. In other parts of the world, beginning farmer training has become a priority for federal programmes given the general aging of the current farmer population. Loss of farmers and their businesses represents a risk to national food security as well as rural community viability.

Limited access to production knowledge, inputs and financial credit can curtail growth and adaptability of any farmer to climate and other challenges, regardless of scale. Access to inputs (e.g., soil amendments, pesticides, fertilizers and packaging) at price points, in appropriate quantities and at locations nearby smallholders' farms, is the first challenge. Understanding the wise and best use of these inputs is yet another hurdle, given language and literacy barriers. Agricultural credit from appropriate and reputable sources, or via community shared savings, can support growth and development of farm enterprises. However, access to such financing may be out of reach for many smallholder farmers.

For many women farmers, secure access to land, whether through secure rights of access, title or long-term lease agreements, is of particular concern. Women's access to agricultural land or any other land is precarious, often accessed through secondary means through natal or marital relationship. Without secure access to land, smallholder farmers and in particular women farmers may have limited feasible or affordable options for restructuring production strategies for climate resilience. Investing in soil quality, for example, requires a long-term view; incentives are few if tenure is questionable.

Many smallholder farmers rely upon direct sales to neighbours or through local farmers' markets. Access to wholesale markets represents a diversification and growth strategy, particularly for situations in which a farmer may be very skilled at growing select crops or raising livestock. Access to wholesale markets is limited by farmer awareness of terms and quality required, economical transportation options to move product to markets and concerns with brokers that siphon profits of sales. While working cooperatively or collaboratively with other farmers to achieve the economies of scale for product volume is an attractive approach, these types of cooperatives are riddled with social and equity challenges that can quickly lead to their undoing. 
Entrepreneurship was defined by Dr Howard Stevenson (Harvard University) as "the pursuit of opportunity beyond resources controlled" (Eisenmann, 2013). Pursuit characterizes the focused attention to an opportunity, which might include new products, markets, models or cost saving strategies. The resources that an entrepreneurial farmer has to leverage are their human, social, natural and financial capitals. They must be creative and take risks to grow their businesses. While central to entrepreneurship is personal agency, or the capacity to act independently and make individual choices, there are many structures (e.g., class, gender, ability) that can influence or limit a smallholder's decisions. Scalable examples of resilient, thriving smallholder farming in SADC are needed to inspire farmers to transition from subsistence to growth.

How can educators build capacity and capability among smallholder farmers to anticipate and adapt to challenges? What are potent strategies in education and engagement that feed the fire of optimism and entrepreneurship? How do training programmes foster dynamic and future-focused "anticipatory" planning required to truly prepare for climate change and other agricultural risks?

\section{Participatory and popular education techniques}

While there are many farming challenges that can be addressed through straightforward technology transfer, these strategies may fall short in securing transformation of smallholder farmer practice. Resilience to climate change and other environmental stresses requires more agro-ecological, integrative farming strategies that include local knowledge, social networks and political economies to build sustainable and equitable systems (Méndez et al., 2013) (Mistry and Berardi, 2016).

Conveying the complexity of agro-ecological system design without assuming advanced education and understanding of biological processes requires a participatory or action-research approach. Indigenous knowledge of a locale's biodiversity and natural resources can provide insights to support adaptation of appropriate solutions (Snapp et al., 2010). Participatory action research is well established as a strategy to support cogeneration of knowledge; the process empowers individual and group action by weaving local knowledge with scientific findings and strengthens trust with outside educators (Snapp and Heong, 2003). The approach allows marginalized communities to give voice to their own knowledge, draw from lived experiences and problem-solve towards their own solutions.

The educator requires skills and careful planning to fully implement these types of participatory approaches. Facilitation strategies for success include how to structure group process, establish working agreements and ensure participation from all members. Collaborative problem identification coupled with cogeneration of solutions by researchers/educators/extensionists strengthens the appropriate application of strategy within the farmers' context.

The Smallholder Horticultural Empowerment and Promotion (SHEP) project provides an example where farmers and implementers co-identify and 
co-implement solutions (JICA, 2019). SHEP has assisted farmers to double their income in Kenya (JICA, 2019) and has been implemented in Lesotho, Malawi, South Africa and Zimbabwe since 2018. Similar to the SHEP model in Kenya, models and case studies of inclusive, empowering educational approaches have been described for agricultural enterprises in South Africa (Mabaya et al., 2011).

\section{Building capacity of service providers}

Most extension agents or other educators come from formal education programmes with specific disciplinary focus. Continuing professional development ensures these front-line individuals' technical knowledge and skills are in sync with current research (e.g., climate risks) or best practices. Prioritizing their engagement directly with farmers is critical to deploying this valuable development resource. Public sector extension work is necessary for the growth of the agriculture in southern Africa but limitations in resources, excessive bureaucratic work and the diversity of extension goals limits transformational success (Raidimi and Kabiti, 2017). Therefore, investments in extension services must be deeply connected with communities to ensure both educator and farmer satisfaction.

Extension personnel are rarely trained in participatory action research strategies, which include facilitation strategies, group or leadership development or nontraditional modes of engagement. Yet, these "soft" skills are essential "tools" in the trainer's toolbox to support transformative change among smallholder farmers. These skills require the educator to constantly be shifting roles, from teacher, to learner, to networker. Dogmatic adherence to a prescribed educational agenda will only serve to document numbers "trained" but none transformed. Policy and strategy must support the mix of skills needed to cultivate dynamic educators with both the foresight and humility to plan thoughtfully before entering communities with "solutions". Participatory engagement, with full commitment and mutual respect among researchers, educators, students and citizens serves to leverage the assets of the whole while also strengthening democracy (Post et al., 2016).

Several of these types of skills are briefly described in the following sections. An example of a comprehensive approach to engaged curriculum focused on agro-ecology and climate change is presented by Bezner Kerr et al. (2019).

\section{Mapping the knowledge ecosystem}

If the goal is to strengthen the human capacity and agency of farmers, the initial focus must be on supporting professional development of those who connect with them regularly. While this will obviously centre on funded agriculture extension officers/educators, the pool of service providers extends to all who impact the viability of these farmers, including NGO agents, agriculture input suppliers, product buyers, financiers, environmental and regional planners, etc. 
Collectively, these individuals represent the knowledge "ecosystem" that supports farm viability. Mapping and understanding the influence of these current and historic actors in a region is essential prior to investing in new training. Engaging this diversity of perspectives will support design of programmes that are reinforced by multiple individuals and farmer contact points. Supporting professional development across these groups, together, could foster greater collaboration towards training goals.

Extension investment in SADC remains sparse, uncoordinated and varied in quality (Zwane and Davis, 2017). In South Africa, extension renewal and evaluation exercises have taken place and identified gaps in policy environment, professionalism, capacity and technical competencies (Davis and Terblanché, 2016). Recent policy investments point to a renewal in agricultural extension through the development of new coordinating bodies that promise to promote farmer development (e.g., New Partnership for Africa's Development's Comprehensive African Agricultural Development Programme (CAADP, 2003) and the Southern Africa Regional Forum for Agricultural Advisory Services (SARFAAS) (Zwane and Davis, 2017).

\section{Mapping of community infrastructure}

Ubuntu is a South African concept that refers to compassion, solidarity and the interdependence of the individual with a community. It speaks to values of caring, sharing, cooperation and compassion. It recognizes that inextricable link among us, summarized as "I am because we are". This principle is at the core of these participatory and asset-based approaches that can build human capacity to support the transformation of agriculture.

Participatory methods build upon this shared South African idea of Ubuntu to foster group action. Several methods can help farmer groups clarify resource assets and constraints. Examples of group activities include participatory mapping, time use surveys, participatory photography and seasonal calendars and focus groups. The participatory activities can uncover shared knowledge, attitudes and perceptions, as complements to individual interviews and case studies. In all cases, the educator/facilitator must consider their role in supporting discussion, having community agreement on that role and setting aside their own knowledge or opinions. These skills require training and coaching to effectively build trust within the community group and maintain open, engaged dialogue and debate.

For example, participatory mapping helps a community and advisors understand the community's relationships to their land, natural resources, community resources and other assets (Corbett, 2009). A set of guiding questions helps participants create their own visual map by first asking them to locate built landmarks (e.g., churches, community centres, roads,) followed by natural resources (water sources, forests), their own homesteads and then agricultural assets (e.g., input suppliers, fences, markets, best soils). Discussion can then focus on uncovering challenges, such as flood zones, best or degraded soils, poor roads 
or transport, social isolation and opportunities for change. Through this activity, communities can be more empowered to share priorities for training from educators or investment from local governments.

Participatory photography is another strategy in which community members can identify, record and then critically discuss opportunities and challenges using the photos as prompts (Wang and Burns, 1997). Given a set of prompts and a camera (cell phones now make this easy), the community members capture images to provide evidence as to their understanding of ecological, production or marketing concepts, their access to resources or the challenges they face individually or as a group. For example, asking farmers if they have a problem with access to water may elicit are vocal response of "no". Yet when they take photos of their water source, it can become clear that hand carrying water from a small stream could in no way support expanding agricultural production. The photos become a focus point for discussion around challenges and solutions. This strategy also allows for full engagement of those who do not read or write in the dominant language used in the community. Images can support much more rich discussion and memorable conclusions, compared to sharing survey or research results.

\section{Mapping the challenges}

Surveys, storytelling, focus groups and other small group discussions can support community inquiry into shared challenges. In addition, dramas can help bring humour into the process, particularly when exploring sensitive issues, such as inequities in access to resources or power differentials (Bezner Kerr et al., 2019). Drama done by facilitators can be used to illustrate complex problems, supporting group discussion and analysis. Subtle shifts in understanding can pave the way for greater farmer confidence in their own knowledge and more openness to collaboration (Bezner Kerr et al., 2019).

Role plays or participatory theatre create active ways for a community to explore issues, analyze possible changes and explore power relations that may impact solutions (Sloman, 2012). The educator/facilitator is essential to "set the stage" with some scenarios that can guide but do not control the creative direction of the role play. The risk is that the outcome can be unpredictable. Yet, these moments provide opportunities for new dialogue. The process can energize a community, strengthen cohesion and be entertaining for all. As a facilitation strategy, role plays and drama can enliven educational programmes and create memorable stories.

\section{Timely knowledge sharing}

Farmer field schools are a popular educational strategy in which groups of farmers gather to inquire and experiment about various agricultural issues of importance to their farms (Sustainet, 2010). The strategy combines traditional education with hands-on or experiential activities, to deepen understanding 
of the problem and context. The farmer groups repeatedly gather at a farm to work together to analyze and solve particular challenges. Critical to the success of this engaging process is a skilled facilitator who has the confidence and ability to guide but not direct, supporting the farmers in sharing their own knowledge (Godrick et al., 2014). Extension personnel need to be trained to facilitate this strategy.

Farmer field schools can build or strengthen farmer networks and collaboration. Unlike field demonstrations, the process uses repeated observations and inquiry by the group. Structuring small experiments or trials together supports peer-to-peer learning, trust building and can lay groundwork for more complicated group activities such as joint marketing of products.

Digital platforms offer new strategies to quickly provide relevant information to farmers or facilitate their sharing information with each other via texting on cell phones (e.g., https://wefarm.co/). Educators have an opportunity to provide advice on planning, inputs, production, harvest, pests and their control, postharvest handling and market pricing - just a few areas in which educators could leverage a digital platform. While the most efficient strategy currently may be texting, short videos or photo sharing will allow for those with limited literacy to participate. Photos can also support rapid diagnosis of pest problems. Data could be shared in a "programmed" manner, according to seasonal calendars (e.g., what diseases/insect and at what growth stages along with available pesticide/fungicide to effectively treat them) or in response to weather anomalies and reach more farmers than possible individual or community field visits.

Another novel example of a small-farm relevant cell phone application is bringing the sharing economy to booking tractors (e.g., www.trotrotractor. com/ or www.hellotractor.com/home). These platforms facilitate tractor services particularly for smallholder and women farmers as well as encourage entrepreneurship and community collaboration.

\section{Evaluation benchmarks}

Investing in strategies to assess and benchmark access to essential agricultural resources can support ongoing development of appropriate and effective programmes aimed at increasing human capacity for African farmers. Of particular interest is tracking progress of women farmers, a significant portion of SADC farmers. The Women Empowerment in Agriculture Index (IFPRI, 2012) outlines five domains for empowerment- production, resources, income, time and leadership. The recent brief by the Technical Center for Agricultural and Rural Cooperation argues for more comprehensive benchmarks or indices to assess women farmers' access to agriculture resources that support entrepreneurship (Adedeji et al., 2019). Included in this index are 1) access to land;2) access to finance; 3) access to markets; 4) access to infrastructure, technology and equipment; 5) access to education and capacity-development resources; 6) access to business information and networks; and 7) access to policymakers/ policy dialogue. These types of indices provide strategies for understanding the 
full ecosystem of factors influencing farmer decision making towards agriculture advancement.

\section{Conclusions and policy recommendations}

Building human capacity of farmers first requires building capacity among extension educators. Learning to do engaged work is not easy. Professional development must start in post-secondary training of extension educators, outfitting them with the facilitation skills and confidence to deploy participatory strategies as easily as technical solutions.

To move from technical service provider to transformative agent will require new skills, confidence and programme design from the educators. Hosting training events and sharing technical information will certainly provide smallholder farmers with choices. Creating an environment to support the personal realizations that precede transformative change and action requires more than traditional technology transfer. Grounding farmer education in participatory or asset-based approaches can foster this progression. The transforming extension agent fosters resilient social networks, guides - not prescribes - and encourages peer-to-peer learning and challenges farmers to grow "beyond resources controlled".

The work of transformation does not lie only with the field extension educator. It includes the network of publicly engaged scholars and university academics, school educators, practitioners, citizens and nonprofit leaders whose knowledge and commitment are needed for long-term capacity building among the target farmers (Uta et al., 2018). A revived and invigourated sense of Ubuntu, or interdependence, among these various actors will support innovation and creative problem solving. Participatory engagement, with full commitment from all stakeholders to yield social learning for all stakeholders, including facilitators, extension researchers, educators and farmers, will best leverage the assets of the whole.

\section{References}

Adedeji, O., M. Sudarkasa, D.R. Campbell and A. Reynier (2019) CTA Technical Brief: Women's Agribusiness Access Index. Technical Center for Agricultural and Rural Cooperation. Wageningen: CTA. Accessed March 2, 2019. https://cgspace.cgiar.org/bitstream/handle/ 10568/99706/2066_PDF.pdf.

Altman M., T.G.B. Hart and P.T. Jacobs (2009) Household food security status in South Africa. Agrekon 48(4): 345-361.

Bezner Kerr, R., S.L. Young, C. Young, M.V. Santoso, M. Magalasi, M. Entz, E. Lupafya, L. Dakishoni, V. Morrone, D. Wolfe, and S.S. Snapp (2019) Farming for change: Developing a participatory curriculum on agroecology, nutrition, climate change and social equity in Malawi and Tanzania. Agriculture and Human Values. Accessed February 20, 2019. https://doi.org/10.1007/s10460-018-09906-x.

Comprehensive Africa Agriculture Development Program (CAADP). (2003) New Partnerships for Africa's Development. www.caadp.net/pdf/CAADP. ISBN 0-620-30700-5. 
Corbett, J. (2009) Good Practices in Participatory Mapping: A Review Prepared for the International Fund for Agricultural Development. Accessed February 22, 2019. www.ifad.org/docu ments/38714170/39144386/PM_web.pdf/7c1eda69-8205-4c31-8912-3c25d6f90055.

Davis, K.E. and S. Terblanché (2016) Challenges facing the agricultural extension landscape in South Africa. South African Journal of Agricultural Extension 44(2): 231-247.

Eisenmann, T.R. (2013) Entrepreneurship: A working definition. Harvard Business Review. https://hbr.org/2013/01/what-is-entrepreneurship.

Godrick, S.K., J. Okoth and E. O'Brien (2014) Farmer Field Schools: Key Practices for DRR Implementers. FAO. Accessed March 10, 2019. www.fao.org/3/a-i3766e.pdf.

Herrero M., P.K. Thornton, B. Power, J.R. Bogard, R. Remans, S. Fritz, J.S. Gerber, G. Nelson, L. See, K. Waha, R.A. Watson, P.C. West, L.H. Samberg, J. van de Steeg, E. Stephenson, and M.van Wij (2017) Farming and the geography of nutrient production for human use: A transdisciplinary analysis. The Lancet Planetary Health 1(1): e33-e42. Accessed February 20, 2019. https://doi.org/10.1016/S2542-5196(17)30007-4.

International Food Policy Research Institute (IFPRI). (2012) Women's Empowerment in Agriculture Index. Accessed May 12, 2019. http://ebrary.ifpri.org/utils/getfile/collection/ p15738coll2/id/126937/filename/127148.pdf.

Japan International Cooperation Agency (JICA). (2019) Smallholder Horticulture Empowerment and Promotion (SHEP). Accessed May 14, 2019. www.jica.go.jp/english/our_work/ thematic_issues/agricultural/shep.html.

Lowder, S.K., J. Soet and T. Raney (2016) The number, size, and distribution of farms, smallholder farms, and family farms worldwide. World Development 87: 16-29. Accessed February 20, 2019. https://doi.org/10.1016/j.worlddev.2015.10.041.

Mabaya, E., K. Tihanyi, M. Kaaran and J. van Rooyen (2011) Case Studies of Emerging Farmers and Agribusinesses in South Africa. Sun Press. ISBN: 978-1-920338-65-7.

Méndez, E.V., C.M. Bacon and R. Cohen (2013) Agroecology as a transdisciplinary, participatory, and action-oriented approach. Agroecology \& Sustainable Food Systems 37: 3-18.

Mistry, J. and A. Berardi (2016) Bridging indigenous and scientific knowledge. Science 352: 1274-1275. Accessed February 12, 2019.

Murphy, S. (2012) Changing Perspectives: Small-scale Farmers, Markets and Globalisation. London/ The Hague: IIED/Hivos. Accessed March 2, 2019. www.ictsd.org/sites/default/files/ downloads/2012/08/changing-perspectives-small-scale-farmers-markets-and-glob alisation-murphy-iied.pdf.

Post, M.A., E. Ward, N.V. Longo and J. Saltmarsh (2016) Publicly Engaged Scholars: Next Generation Engagement and the Future of Higher Education. Sterling, Virginia: Stylus Publishing. p. 286.

Raidimi, E.N. and H.M. Kabiti (2017) Agricultural extension, research, and development for increased food security: the need for public-private sector partnerships in South Africa. South African Journal of Agricultural Extension 45(1): 49-63.

Sloman, A. (2012) Using participatory theatre in international community development. Community Development Journal 47(1): 42-57. Accessed February 15, 2019. https://doi. org/10.1093/cdj/bsq059.

Snapp, S.S and K.L. Heong (2003) Scaling up: Participatory research and extension to reach more farmers. In: Managing Natural Resources for Sustainable Livelihoods: Uniting Science and Participation.Eds. B. Pound, S, Snapp, C. McDougall and A. Braun. UK: Earthscan. pp. 67-87.

Snapp, S.S., J. Malcolm, B. Blackie, R.A. Gilbert, R. Bezner Kerr and Y.G. Kanyama-Phiri. (2010) Biodiversity can support a greener revolution in Africa. Proceedings of the National Academy of Sciences 107: 20840-20845. Accessed February 20, 2019. www.pnas.org/ content/107/48/20840. 
Sonia, Murphy (2012). Changing Perspectives: Small-scale farmers, markets and globalisation. London/ The Hague: IIED/Hivos. Accessed March 2, 2019. https://www.ictsd.org/sites/default/ files/downloads/2012/08/changing-perspectives-small-scale-farmers-markets-and-glob alisation-murphy-iied.pdf.

Sustainet, E.A. (2010) Technical Manual for Farmers and Field Extension Service Providers: Farmer Field School Approach. Nairobi, Kenya: Sustainable Agriculture Information Initiative. Accessed December 2, 2019. www.sustainetea.org/downloads/file/11-farmer-fieldschool-approach.html.

Tschakert, P. and K.A. Dietrich (2010) Anticipatory learning for climate change adaptation and resilience. Ecology and Society. Accessed February 20, 2019. www.ecologyandsociety. org/vol15/iss $2 / \operatorname{art} 11 /$.

Uta, W.U., K. Collins, K. Anema, L. Basco-Carrera and A. Lerebours (2018) Stakeholder engagement in water governance as social learning: Lessons from practice. Water International 43(1):34-59.

Wang, C. and M.A. Burns. (1997) Photovoice: Concept, methodology, and use for participatory needs assessment. Health Education and Behavior 24(3): 369-387.

Wiggins, S. and S. Keats. (2013) Smallholder Agriculture's Contribution to Better Nutrition. Overseas Development Institute. Accessed February 19, 2019. www.odi.org/sites/odi.org.uk/ files/odi-assets/publications-opinion-files/8283.pdf.

Zwane, E.M. and K.E. Davis (2017) Extension and advisory services: The African renaissance. South African Journal of Agricultural Extension 45(1): 78-89. 